\title{
Analysis of Student Learning Difficulties by Using the GQGA Application during the Covid-19 Pandemic
}

\author{
Meryance Viorentina Siagian ${ }^{* 1}$, Alwin Fau ${ }^{2}$ \\ ${ }^{* 1}$ Lecturer, Information Technology Education, Faculty of Teacher Training and Education, Budi Darma \\ University, Medan, North Sumatra, Indonesia \\ ${ }^{2}$ Lecturer, Information Systems, Faculty of Computer Science and Information Technology, Budi Darma \\ University, Medan, North Sumatra, Indonesia
}

\begin{abstract}
Article Info

Volume 8, Issue 6

Page Number : $164-169$

\section{Publication Issue}

November-December-2021

\section{Article History}

Accepted : 01 Nov 2021

Published : 14 Nov 2021

The purpose of this study was to analyze the learning difficulties experienced by students using the GQGA application during the covid-19 pandemic. This research is qualitative research using descriptive research methods. The implementation of this research was carried out on Budi Darma University students for the 2020/2021 academic year. Collecting data for this study in the form of observations, tests, and interviews. From this research, the result is a learning media in the form of an application that is used in learning mathematics. The results of the analysis show that the existence of this GQGA application can help improve student learning outcomes better, this can be seen from the completeness value of student test results, namely as many as 130 students who completed with a percentage of $86.09 \%$. Interviews with students also showed positive responses to the use of the GQGA application, because this application makes it easier to understand mathematical symbols, saves time in the learning process, and helps students to be more active in asking and answering questions during the covid-19 pandemic.
\end{abstract}

Keywords : Learning Difficulties, GQGA Application, Covid-19 Pandemic

\section{INTRODUCTION}

Learning difficulties are an obstacle experienced by students in solving a problem related to questions that require counting skills, understanding concepts, and operating numbers. Problems that are difficult for students to solve are usually in the form of story questions. In which students are often mistaken or unable to understand the meaning of the questions and are confused when operating the questions.[1]

Not only that learning difficulties are also experienced by students in educational institutions, especially in universities. Where learning difficulties are defined as difficult conditions in meeting the standards of a subject and getting certain obstacles in the reasoning process of learning.[2] 
Learning difficulties or obstacles experienced by students can be caused by two factors, namely internal and external factors. The internal factors are factors that come from within the student, for example, health, talent, interest, motivation, intelligence, and so on, while external factors are factors that come from outside the student, for example from the school environment, family, and community. Learning difficulties experienced by students are a condition that has an impact on the student's personal ability to master the learning objectives to be achieved, such as the difficulty of errors in understanding questions, thinking process skills, inaccuracy in working on questions, and managing the time provided. One of the subjects that are considered difficult by students is a course related to mathematics, namely calculus. Some of the difficulties experienced by students in studying calculus courses are weak students in understanding basic calculus concepts, forgetting lessons related to arithmetic operations during school, and lack of practice in working on integral problems.[3]

Based on the results of observations made at Budi Darma University, there were $26 \%$ of students with D grades and $14 \%$ with $\mathrm{E}$ grades. This certainly shows that many students do not pass mathematics courses. Not only that, but students also complained that mathematics courses were difficult to understand both in terms of material presentation and delivery, especially because of the online process. Therefore, with the implementation of this online process, there is a decrease in learning in every educational institution.[4]

The occurrence of this online process is due to the Covid-19 that hit the earth. Since March 21, 2020, it was recorded that the Coronavirus has spread to 167 countries and more than 285,000 cases with nearly 12,000 deaths worldwide.[5] Not only death, but this virus has also made the country of Indonesia experience a decline in every educational competency.[6] Therefore, it is hoped that there will be improvements both in terms of curriculum, learning methods, and the development of teaching materials in universities and lecturers are required to be able to achieve learning goals by designing and utilizing various types of media, models, and learning sources that can make students actively express opinions or ideas. and motivated to learn better so that the learning process takes place effectively and efficiently.

The Giving Question and Getting Answer (GQGA) model is the implementation of a constructivist learning strategy that places students as subjects in learning. This model provides opportunities for students to be more active in expressing their opinions, being more daring to ask questions, and helping students better understand the material being taught.[7] Not only that, this model has a good impact on the performance of teachers in carrying out learning. [8]

This Giving Question and Getting Answer (GQGA) model is also a cooperative model that demands a high intellectual learning process from students, to train students to keep thinking in their reasoning process.[9] The Giving Question and Getting Answer (GQGA) model is widely applied using worksheets in the form of pieces of paper that are given to students by completing various questions related to the material and forming groups and later each group chooses an existing question and has been selected to be read out. and answered.[10] In this era of technological advancement, it is no longer effective to use worksheets which are the old way of applying a model. Especially during this Covid-19 period, it is not appropriate to use it, because, during this Covid19 period, it forces us to learn more about the use of technology and be creative in developing each learning media.[11] 
This is certainly not easy for every teacher to carry out learning, especially in this Covid-19 era which requires not meeting face to face, and only using technology as the most important supporting tool in the learning process. Because of this, the author applies the Giving Question and Getting Answer (GQGA) Model to an application that will be used in the learning process. To align student habits towards gadgets and the sophistication of internet technology.[12]

Making an application in the application of the Giving Question and Getting Answer (GQGA) Model aims to facilitate every access and activity to increase the enthusiasm of students' learning and reduce the scope of the inability to understand a mathematics lesson and simplify the process without having to meet face to face, and is very helpful during the global Covid-19 outbreak and under normal conditions.[13] The application of this GQGA application supports the realization of an intelligent society in dealing with the development of the use of the digital world in helping every problem of educators and students in understanding learning difficulties both online and offline as well as expanding the period of use anywhere and anytime. This application is applied to the online learning process of mathematics courses and is designed according to the purpose so that the implementation of learning runs effectively and efficiently. This application is also one of the learning media that makes it easier for lecturers to provide information to students related to symbols or symbols that have meaning and can be used in solving problems related to mathematics.[14]

Based on the above background, this study aims to analyze student learning difficulties using the GQGA Application during the covid-19 pandemic.

\section{METHODS}

This type of research is qualitative research using descriptive research methods. This research was conducted on Budi Darma University students who took mathematics courses for the 2020/2021 academic year. To obtain data in this study, this study used tests and interviews to analyze student learning difficulties by using the GQGA application on mathematics material. To calculate the test results used the percentage of classical learning completeness. This classical mastery of learning is declared successful if the percentage of students who complete learning is $85 \%$ of the total number of students. The results of this analysis are used as reflection material to carry out further design or improvement of learning designs on applications that will be applied in each meeting or subsequent cycle.

\section{RESULTS AND DISCUSSION}

The results of this study are in the form of a GQGA application with various application views as follows:

\section{A. Lecturer Dashboard}

On the lecturer dashboard page, there is a menu of questions to be given to students, classes taught by lecturers, students, schedules to enter class and answers to questions or exams, and logout from the application.

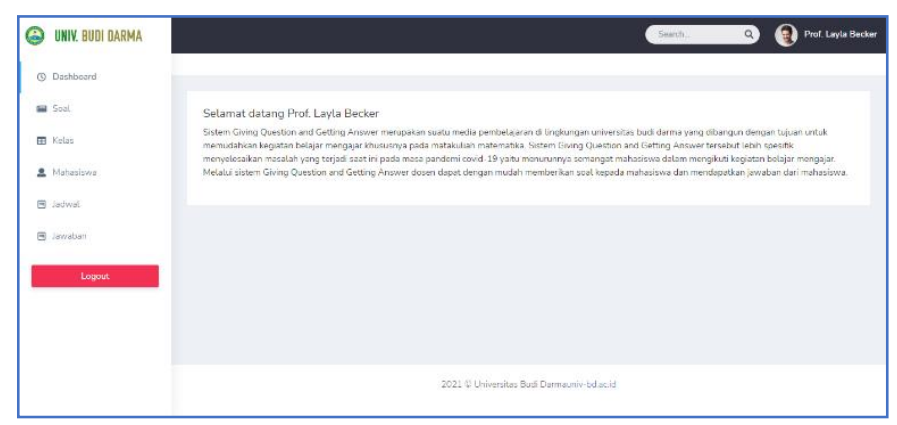

Figure 1: Lecturer login screen

\section{B. Student Dashboard}

After the student logs in and is successful, they will be directed to the student's main page which consists of menus: Home, Guide, Schedule, and Logout. 

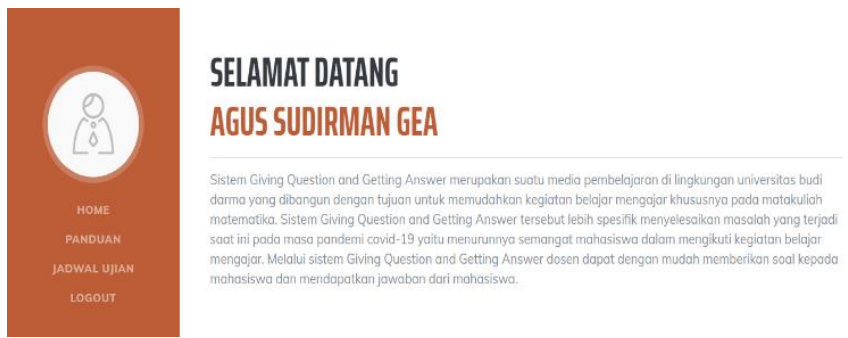

Figure 2: Student login screen

\section{Lecturer Gives Questions}

The first step to give questions is to determine the implementation schedule, in the form, specify the class, course, and date of implementation, then proceed to the selection of questions. The questions given by the lecturer to students are in the form of math problems.

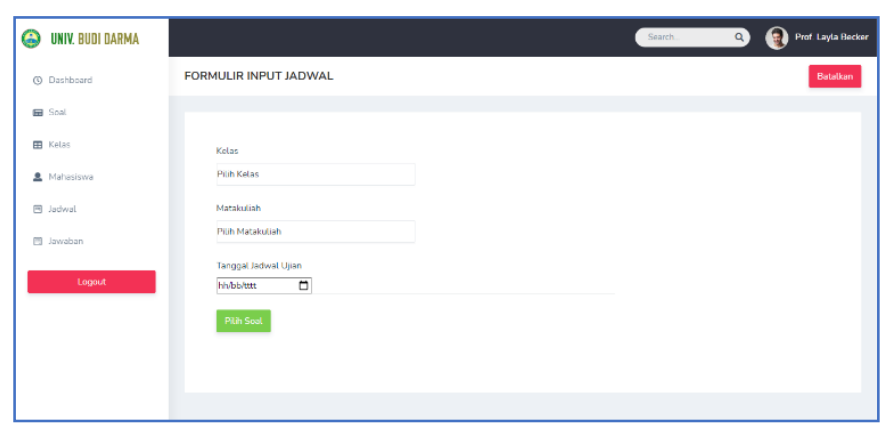

Figure 3: Schedule input display

On that page, specify the questions to be used and their order by ticking the questions and filling in the order. Here are some of the questions given by the lecturer:

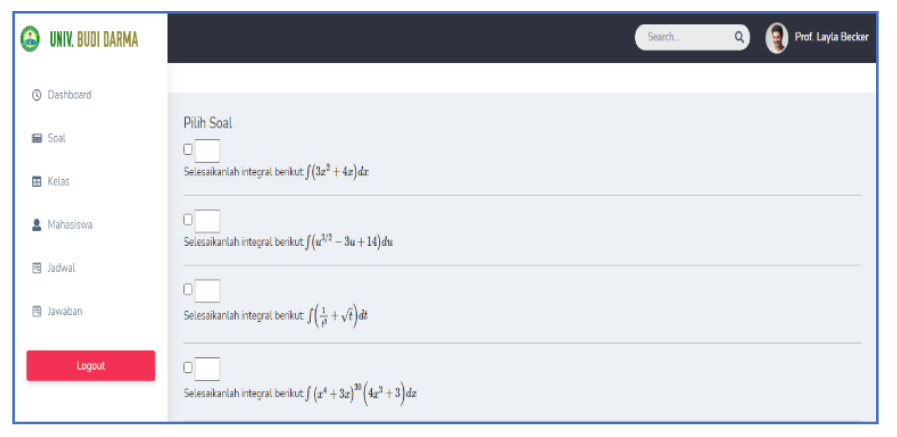

Figure 4: Question Display

\section{Student Answer Questions}

The initial step taken by students is to choose an implementation schedule according to the time determined by the lecturer, either when attending lectures online or during exams.

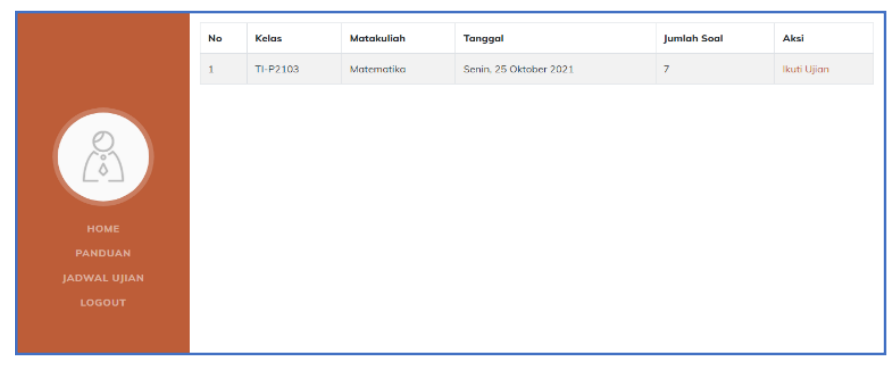

Figure 5: Schedule view

In this display, questions will appear one by one under the order of the questions that have been determined and students answer each question given on a worksheet that contains mathematical symbols and students no longer need to work on the problem manually. From the display below, it can be seen that the symbol when clicked will display more mathematical symbols, such as the symbols on the Equation menu in Microsoft.

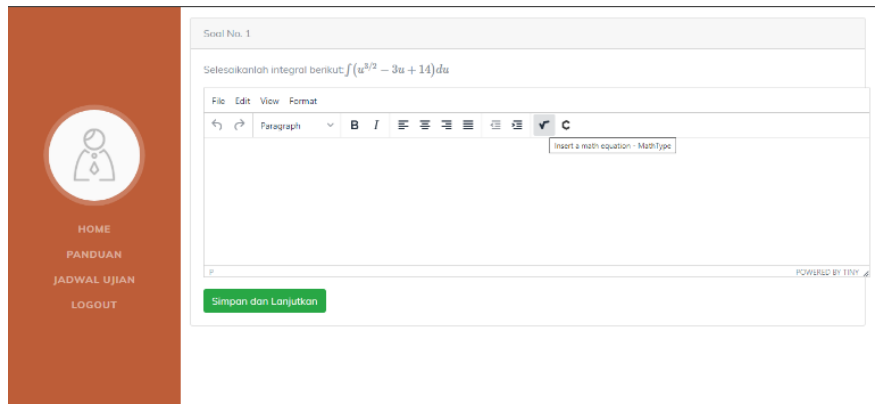

Figure 6: Worksheet view

\section{E. Lecturers Get Answers}

Questions that have been answered by students can be seen by the lecturer through the answer menu on the lecturer dashboard. From the questions that have been answered by the student, the lecturer analyzes the results of student work to see the difficulty of students answering each question given. The 
questions given are related to mathematics courses on integral material.

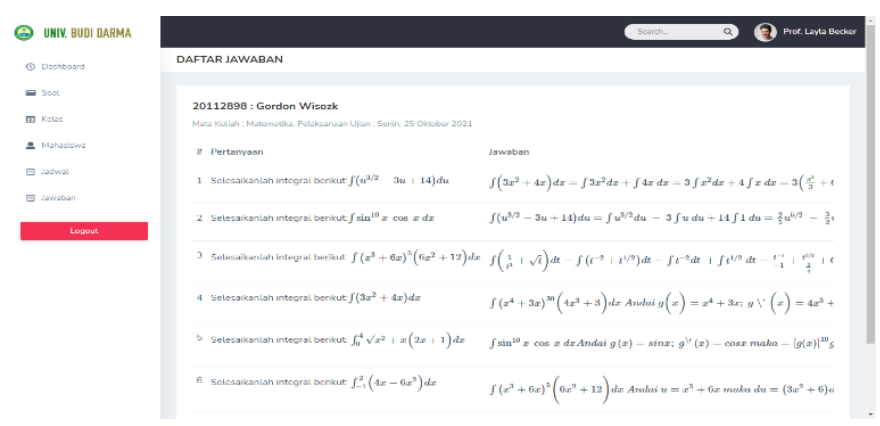

Figure 7: Display of answers

From the appearance of the GQGA application above, they feel that they are more able to work on every given question, because it is easier and faster to work on each question than manually, more independent and responsible in doing the tasks given by the lecturer, gaining new knowledge and experience regarding the application used. for lectures in class and online processes, getting enough time to do assignments given by lecturers directly or indirectly, students feel more comfortable using the internet optimally.[15]

\section{IV.CONCLUSION}

Based on the results of the analysis of the data discussed above, it can be concluded that the GQGA application can help improve student learning outcomes in learning mathematics, especially in integral material. The improvement in learning outcomes is quite good, which is indicated by each answer process given by students when the learning process takes place online using the GQGA application, where students understand better the use of symbols in the application and their application in every question given by the lecturer. Not only that, but student activity is also quite high in asking questions, answering questions from lecturers or other students online, this application can also be used if the learning process is directly in the classroom and this application can also be used in other related subjects. with mathematics, be it calculus, basic mathematics, engineering mathematics, matrices, and linear transformations, or the same as these subjects. This application also makes it easier for students to collect assignments according to the deadlines given by the lecturer because they no longer need to be done manually and then collected directly, but simply do it in the worksheet on the application then click save and continue. Then all students' answers will appear which can be seen and assessed by the lecturer.

\section{REFERENCES}

[1]. D. R. Utari, M. Y. S. Wardana, and A. T. Damayani, "Analisis Kesulitan Belajar Matematika dalam Menyelesaikan Soal Cerita," J. Ilm. Sekol. Dasar, vol. 3, no. 4, pp. 532-540, 2019, Online]. Available: ttps://ejournal.undiksha.ac.id/index.php/JISD/in dex\%0D.

[2]. D. Apriandi and I. Krisdiana, "Analisis Kesulitan Mahasiswa Dalam Memahami Materi Integral Lipat Dua Pada Koordinat Polar Mata Kuliah Kalkulus Lanjut," J. Pendidik. Mat., 2016,

doi:

ejournal.radenintan.ac.id/index.php/aljabar/article/view/19/18.

[3]. E.- Monariska, "Analisis kesulitan belajar mahasiswa pada materi integral," J. Anal., 2019, doi: $10.15575 /$ ja.v5i1.4181.

[4]. S. E. N. S. Sinaga, “Analisis Respon Mahasiswa Terhadap Pembelajaran Online di STAIN Sultan Abdurrahman Kepri," TANJAK J. Educ. Teach., vol. 1, no. 2, pp. 137-145, 2020.

[5]. K. J. Clerkin, J. A. Fried, and J. Raikhelkar, "Corona_virus Disease 2019 (COVID-19) and Cardiovascu_lar Disease," Circulation, vol. 141, no. 20, pp. 1648-1655, 2020, Online]. Available: https://pubmed.ncbi.nlm.nih.gov/32200663/. 
[6]. F. I. Hermansyah, "Pengambilan Kebijakan oleh Swedia dan Indonesia terhadap Pandemi Covid19," J. Virol., pp. 1-14, 2020.

[7]. F. Yulianti, Sutrio, and H. Sahidu, "Pengaruh Model Giving Question Getting Answers Melalui Metode Eksperimen Terhadap Motivasi Dan Hasil Belajar Fisika," ORBITA, vol. Volume 6, no. Nomor 1, pp. 173-180, 2020.

[8]. Nurhasni, "Penerapan Model Pembelajaran Giving Question And Getting Answer Untuk Meningkatkan Kinerja Guru Dalam Mengajar DI SMPN 4 MINAS," PAJAR (Pendidikan dan Pengajaran), vol. 1, no. 2, pp. 200-207, 2017.

[9]. A. Octaviyunas and A. Ekayanti, "Pengaruh Model Pembelajaran Giving Question Getting Answer dan Think Pair Share terhadap Kemampuan Penalaran Matematika Siswa Kelas VII," Mosharafa J. Pendidik. Mat., vol. 7, no. 3, pp. 341-352, 2019, Online]. Available: http://journal.institutpendidikan.ac.id/index.ph $\mathrm{p} / \mathrm{mosharafa}$.

[10]. Y. D. Kurino, "Model Giving Question and Getting Answer Untuk Meningkatkan Hasil Belajar Siswa Sekolah Dasar," Didact. Math., vol. 1, no. 1, Nov. 2018, doi: 10.31949/dmj.v1i1.1122.

[11]. D. I. S. Hapsari and S. Fahmi, "Pengembangan Media Pembelajaran Interaktif Berbasis Android Pada Operasi Pada Matriks," FIBONACCI J. Pendidik. Mat. dan Mat., vol. 7, no. 1, pp. 51-60, 2021.

[12]. B. R. A. Febrilia, I. C. Nissa, Pujilestari, and D.

U. Setyawati, "Analisis Keterlibatan Dan Respon Mahasiswa Dalam Pembelajaran Daring Menggunakan Google Classroom Di Masa Pandemi Covid-19," FIBONACCI J. Pendidik. Mat. dan Mat., vol. 6, no. 2, pp. 175-184, 2020.

[13]. Maryani, F. L. Gaol, and T. Matsuo, "The Digital Transformation of Enterprise Architecture on Culinary SMEs: A Case Study Culinary SMEs in DKI Jakarta Province," Int. J.
Innov. Creat. Chang., vol. 14, no. 2, pp. 257289, 2020.

[14]. E. W. Pratiwi, "Dampak Covid-19 Terhadap Kegiatan Pembelajaran Online Di Sebuah Perguruan Tinggi Kristen Di Indonesia," Perspekt. Ilmu Pendidik., vol. 34, no. 1, pp. 1-8, 2020, doi: doi.org/10.21009/PIP.341.

[15]. A. E. Irawati and D. Setyadi, "Pengembangan EModul Matematika pada Materi Perbandingan Berbasis Android," J. Cendekia J. Pendidik. Mat., vol. 5, no. 3, pp. 3148-3159, 2021, Online]. Available: https://jcup.org/index.php/cendekia/article/view/467/50 4.

\section{Cite this article as :}

Meryance Viorentina Siagian, Alwin Fau, "Analysis of Student Learning Difficulties by Using the GQGA Application during the Covid-19 Pandemic", International Journal of Scientific Research in Science and Technology (IJSRST), Online ISSN : 2395-602X, Print ISSN : 2395-6011, Volume 8 Issue 6, pp. 164-169, November-December 2021. Available at doi : https://doi.org/10.32628/IJSRST21868 Journal URL : https://ijsrst.com/IJSRST21868 